Al-Hikmah: Jurnal Studi Agama-Agama

ISSN: 2407 - 9146 (Print), ISSN: 2549 - 5666 (Online)

Website: http://journal.um-surabaya.ac.id/index.php/Ah/index

DOI: http://dx.doi.org/10.30651/ah.v7i2.5417

Volume 7, No. 2, 2021 (218-234)

\title{
STRATEGI MAJELIS PEMBINA KESEHATAN UMUM MUHAMMADIYAH MELAWAN PANDEMI COVID 19
}

\author{
Mahmud Muhsinin \\ Mahasiswa Program Doktor PAI Universitas Muhammadiyah Malang \\ Romelah \\ Dosen Program Doktor PAI Universitas Muhammadiyah Malang
}

\begin{abstract}
The COVID-19 outbreak has become an epidemic that is experienced by all nations and countries on this earth. Its distribution has been evenly distributed in all countries. Indonesia itself has experienced this plague for one year so far this epidemic has not disappeared. Various elements of society participated in tackling the COVID-19 outbreak, including Muhammadiyah. Muhammadiyah Hospital is a private hospital that is at the forefront in tackling the covid 19 outbreak. This alertness is the result of the guidance carried out by Muhammadiyah for its charities, in this case carried out by the Muhammadiyah Public Health Supervisory Council. What is the strategy of the Muhammadiyah Public Health Board of Trustees in the fight against the Covid-19 pandemic? this is the aim of this research. The type of research that will be used is qualitative research. Qualitative research is a method for exploring and understanding meaning. Inductive-style research perspective, focuses on specificity. The object of research is natural, data collection uses triangulation techniques, data analysis is inductive. The results of the study emphasize more on meaning. The purpose of this study is to formulate the strategy of the Muhammadiyah health council during the pandemic and post-pandemic periods. The results showed that the coaching process by the Muhammadiyah Public Health Supervisory Council was carried out in stages, starting from aligning and equating the employee's life vision with the business charity vision, namely following the vision and mission of Muhammadiyah. The second process instills belief or the spirit of business charity, which follows the spirit and beliefs of the Muhammadiyah movement. The third process is to act in accordance with the provisions of business charity, which follows the practice of Muhammadiyah residents.
\end{abstract}

Keywords: Development Strategy, MPKU Muhammadiyah, covid 19 pandemic

Received: November 20, 2021; Accepted: November 30, 2021; Available online: November, 30, 2021 


\section{Pendahuluan}

Pandemi Covid-19 sudah berlangsung selama satu tahun lebih, sejak kasus pertama diumumkan oleh Presiden Joko Widodo pada 2 Maret 2020 lalu. Bahkan, saat ini kasus Covid-19 di Indonesia tembus 1 juta tepatnya 1.341.314 orang terinfeksi Covid-19.

Kasus penyebaran covid 19 bermula dari kota Wuhan, Provinsi Hubei, Tiongkok pada Desember 2019, beberapa pasien mendatangi rumah sakit di pusat kota Wuhan dengan keluhan penyakit yang belum pernah dikenal. Dari hasil investigasi kemudian dilaporkan bahwa penyakit itu berasal dari virus yang belum diketahui. Kemudian tanggal 31 Desember 2019 dilaporkan ke WHO PBB tentang virus baru ini. pada 1 Januari, Organisasi Kesehatan Dunia (World Health Organization/WHO) membuat sebuah tim untuk menghadapi kemungkinan pandemi. Tanggal 9 Januari 2020, kasus kematian pertama di Wuhan. ${ }^{1}$ Virus ini kemudian oleh Komite Internasionl untuk Taksonomi Virus (ICTV) diberi nama Severe Acute Respiratory Syndrome Coronavirus 2 (SARS-Cov-2), dan oleh WHO penyakitnya diberi nama Covid-19, yang merupakan singkatan dari Coronavirus Disease 2019. ${ }^{2}$

Tanggal 2 Maret 2020, Presiden Jokowi bersama jajarannya mengumumkan kasus pertama positif COVID-19 di Indonesia. Disebutkan, ada dua orang WNI yang terinfeksi virus Corona, yakni seorang ibu (64) dan anak (31) di Depok, Jawa Barat. Mereka tertular COVID-19 dari seorang warga negara Jepang yang sempat ke Indonesia pada Februari 2020. Hanya butuh waktu 38 hari untuk COVID-19 menginfeksi seluruh provinsi di Indonesia, yakni pada tanggal 9 April $2020 .^{3}$

Menurut data WHO tertanggal 26 maret 2021 ada 125 juta jiwa yang terinfeksi virus covid 19 dengan jumlah kasus meninggal mencapai 2.748.737 dengan penyebaran

\footnotetext{
${ }^{1}$ https://www.liputan6.com/health/read/4323369/menilik-awal-mula-perjalanan-covid-19-pada-31desember-2019 diakses tanggal 2 april 2021

2 http://indonesiabaik.id/infografis/mengenal-hubungan-covid-19-dan-sars-cov-2 diakses tgl 2 april 2021

${ }^{3}$ https://health.detik.com/berita-detikhealth/d-5240992/perjalanan-8-bulan-pandemi-virus-coronacovid-19-di-indonesia diakses tanggal 2 april 2021
} 
virus yang merata di seluruh dunia. ${ }^{4}$ Wabah virus covid 19 merupakan musibah yang menimpa seluruh umat manusia.

Demikianlah penyebaran virus covid 19 sangat cepat dan menyebar ke suluruh penjuru dunia. Saat ini tertanggal 2 april 2021 kasus covid 19 di Indonesia mencapai 1.520.000 kasus, dengan kesembuhan 1.360.000 dan kematian mencapai 41.054 jiwa.

Bidang kesehatan bersinggungan langsung dengan dampak pandemi covid 19 ini. Rumah Sakit menjadi dampak awal dari pandemi covid 19 ini. Sejumlah rumah sakit di Tanah Air terancam bangkrut akibat pandemi COVID-19 yang berkepanjangan. Rata-rata pendapatan rumah sakit bahkan anjlok hingga 50 persen. Hal ini pun lantas membuat para pengelola rumah sakit kesulitan untuk menutupi biaya operasional. Beban rumah sakit juga semakin tinggi dalam menangani pasien COVID-19. Ada pula rumah sakit yang sudah terancam kolaps di depan mata akibat dampak kondisi pandemi wabah corona yang berkepanjangan ini. ${ }^{5}$

Bagi rumah sakit rujukan COVID-19, melonjaknya jumlah pasien arus kas terganggu, uang muka kerja (10-50\%) tidak lagi mencukupi biaya operasional, ditambah persoalan dispute klaim dan belum ada kejelasan kapan berakhir masa pandemi COVID19. Rumah sakit non rujukan COVID-19 mengalami penurunan kunjungan pasien non COVID-19. Pemasukan rumah sakit turun antara 30-50\%, memasuki Kondisi New Normal. ${ }^{6}$

Permasalahan tersebut diatasi dengan melakukan efesien operasional, melakukan perubahan SOP, mendesain ulang ruangan untuk kenyamanan dan keamanan pengunjung sesuai protokol kesehatan covid 19, meminimalkan tatap muka, pemanfaatan TIK untuk sosialisasi ke masyarakat, dan transaksi pembayaran diarahkan non-tunai.

Peran muhammadiyah dalam menanggulangi pendemi covid 19 sangat dirasakan oleh masyarakat bahkan pemerintah memberi apresiasi atas peran Muhammadiyah dalam

\footnotetext{
${ }^{4}$ WHO Coronavirus (COVID-19) Dashboard | WHO Coronavirus Disease (COVID-19) Dashboard diakses tanggal 2 april 2021

${ }^{5}$ https://www.viva.co.id/berita/nasional/1226139-pendapatan-anjlok-banyak-rumah-sakit-terancambangkrut-akibat-pandemi diakses tanggal 4 April 2021

${ }^{6}$ https://kumparan.com/pandangan-jogja/pandemi-covid-19-membuat-keuangan-rumah-sakitterancam-bangkrut-1tgkkVYZoj8/full diakses tanggal 4 april 2021
} 
penanggulangan pendemi covid 19. Peran muhammadiyah sangat disanjung dan dibanggakan oleh banyak kalangan hingga pemerintah mengakui peran Muhammadiyah dalam menanggulangi wabah covid $19 .^{7}$

Bagaimana strategi Majelis Pembina Kesehatan Umum Muhammadiyah dalam menanggulangi wabah covid 19 ? dan Bagaimana strategi rumah sakit Muhammadiyah dalam menghadapi pandemi covid 19 ? Pertanyaan ini menjadi tujuan dari penelitian ini. Belajar dari Muhammadiyah dalam hal ini merupakan sebuah keniscayaan untuk diambil hikmah dan pelajaran guna menghadapi masa new normal pasca pandemi covid 19. Sebab respon Muhammadiyah dalam menanggulangi pendemi covid 19 sangat cepat. Muhammadiyah berperan aktif dalam menanggulangi pendemi covid 19.

Jenis penelitian yang akan digunakan adalah penelitian kualitatif. Penelitian kualitatif merupakan metode untuk mengeksplorasi dan memahami makna. Cara pandang penelitian bergaya induktif, berfokus pada kekhususan. Secara rinci pengertian penelitian kualitatif adalah metode penelitian yang berlandaskan pada filsafat postpositivisme, yang memandang realitas sosial sebagai sesuatu yang kompleks, holistik/utuh, dinamis, penuh makna, dan saling berhubungan. Objek penelitian bersifat alamiah, pengumpulan data menggunakan teknik trianggulasi, analisa data bersifat induktif. Hasil penelitian lebih menekankan makna. Tujuan penelitian ini adalah merumuskan strategi majelis kesehatan Muhammadiyah ketika masa pandemi dan masa pasca pandemi.

\section{Pembahasan}

Gerakan Muhammadiyah tidak hanya di sektor pendidikan saja, Muhammadiyah sejak berdirinya di tahun 1912, mengaplikasikan dakwah dalam bentuk karya kongkrit di bidang pendidikan, sosial, ekonomi, pemberdayaan masyarakat dan juga kesehatan. Di Bidang kesehatan dakwah Muhammadiyah telah menjelma dalam bentuk Rumah Sakit dan Klinik yang tersebar di seluruh Indonesia. ${ }^{8}$

Sejarah awal tercetusnya RS PKU Muhammadiyah adalah dari rapat yang digelar oleh KH. Ahmad Dahlan. Beliau menanyakan apakah ada bangunan yang masih perlu

7 https://www.antaranews.com/berita/1846888/jokowi-apresiasi-peran-muhammadiyah-padakesehatan-dan-ekonomi diakses 18 april 2021

${ }^{8}$ Muhammadiyah Membangun Kesehatan Bangsa | Suara Muhammadiyah diakses tanggal 2 april 2021

Al-Hikkmah: Jurnal Studi Agama-Agama/Vol. 7 , No. 2, 2021 
untuk didirikan. Kemudian, KH. Sudja' mengusulkan membangun sebuah Rumah Sakit untuk warga Muhammadiyah. Rapat ini adalah rapat pimpinan pengurus Muhammadiyah yang dipimpin KH Ahmad Dahlan. Hasil rapat ini memutuskan tiga gagasan penting, yaitu Rumah Sakit, Rumah Miskin, dan Panti Asuhan. ${ }^{9}$

Berdirinya klinik dan poliklinik Muhammadiyah pertama, pada tanggal 15 Febuari 1923 oleh KH Ahmad Dahlan atas inisiatif muridnya KH Sudjak. Klinik ini bernama Penolong Kesengsaraan Oemoem (PKO) dengan lokasi pertama di kampung Jagang Notoprajan No.72 Yogyakarta. Tujuan pendidirian klinik ini adalah menyediakan layanan kesehatan bagi kaum dhuafa'.

Pada tahun 1928 klinik dan poliklinik PKO Muhammadiyah pindah lokasi ke Jalan Ngabean No.12 B Yogyakarta (sekarang Jalan K.H. Ahmad Dahlan). Pada tahun 1936 klinik dan poliklinik PKO Muhammadiyah pindah lokasi lagi ke Jalan K.H. Dahlan No. 20 Yogyakarta hingga saat ini. Pada tahun 1970-an status klinik dan poliklinik berubah menjadi RS PKU Muhammadiyah Yogyakarta. ${ }^{10}$

Bersamaan dengan berkembangnya berbagai amal usaha di bidang kesehatan, maka Pimpinan Pusat perlu mengatur gerak kerja dari amal usaha Muhammadiyah bidang kesehatan melalui Surat Keputusan Pimpinan Pusat Muhammadiyah No 86/SK-PP/IVB/1.c/1998 tentang Qaidah Amal Usaha Muhammadiyah Bidang Kesehatan. Dalam Surat Keputusan tersebut diatur tentang misi utamanya untuk meningkatkan kemampuan masyarakat agar dapat mencapai derajat kesehatan yang lebih baik, sebagai bagian dari upaya menuju terwujudnya kehidupan yang sejahtera dan sakinah sebagaimana dicitacitakan Muhammadiyah.

Majelis Pembina Kesehatan Umum

Majelis Pembina Kesehatan Umum (MPKU) Pimpinan Pusat (PP) Muhammadiyah adalah sebuah Majelis yang mengampu program kesehatan yang ada di

\footnotetext{
${ }_{9}^{9}$ https://www.umy.ac.id/pku-muhammadiyah-ide-briliant-kh-sudja-yang-ditertawakan.html diakses 17 april 2021

10

https://rspkujogja.com/2014/09/07/sejarah/\#: :text=RS\%20PKU\%20Muhammadiyah\%20Yogyakart a\%20milik,kampung\%20Jagang\%20Notoprajan\%20No.72 diakses tanggal 16 april 2021
}

Al-Hikkmah: Jurnal Studi Agama-Agama/Vol. 7 , No. 2, 2021 
Muhammadiyah. Majelis ini dulu namanya Majelis Kesehatan dan Kesejahteraan Masyarakat dan mengalami perubahan setelah Muktamar 46 di Yogyakarta.

Berdasarkan hasil perubahan di Muktamar 46, majelis memiliki visi baru sebagai berikut : penggerak utama terwujudnya jejaring antar kelompok social yang mendukung masyarakat sehat dan mandiri. Majelis ini betujuan untuk menciptakan masyarakat yang sehat, menjaga kesehatan menjadi hal yang penting bagi majelis ini. Bagaimana agar masyarakat bisa tetap sehat.

Disusun program kerja secara berkala sebagai berikut; di tahun 2010 majelis bertindak sebagai Penggerak terwujudnya infrastruktur kesehatan dan dinamika kelompok sosial. Infrastruktur kesehatan berupa poliklinik dan rumah sakit didirikan dan dilakukan pembinaan. Di tahun 2015 majelis bertindak sebagai Penggerak terwujudnya masyarakat sehat. Kemudian di tahun 2020 majelis bertindak sebagai Penggerak utama terwujudnya jejaring antar kelompok social yang mendukung masyarakat sehat dan mandiri.

Misi majelis saat ini adalah : Muhammadiyah sebagai gerakan dakwah, mengemban misi di bidang kesehatan sebagai berikut: Pertama; Berperan aktif dalam mewujudkan masyarakat yang berperilaku sehat dan memanfaatkan pelayanan kesehatan yang bermutu. Kedua; Menggerakkan terwujudnya infrastruktur kesehatan yang berkualitas serta dinamika kelompok sosial yang berkesinambungan.

Embrio majelis ini adalah Bagian PKO (Penolong Kesengsaraan Oemoem) yang dibentuk oleh KH Ahmad Dahlan. Waktu itu KH Ahmad Dahlan membentuk 4 Bagian yang menjadi empat unsur pembantu pimpinan sebagai institusi pelaksana PP Muhammadiyah. Bagian-bagian tersebut adalah : Bagian Tabligh, Bagian Sekolahan, Bagian PKO dan Bagian Taman Pustaka. Poliklinik PKO itulah yang menjadi embrio berdirinya RS-PKU dan berbagai lembaga pelayanan kesehatan dan sosial Muhammadiyah yang kini berkembang luas di seluruh Tanah Air.

Misi PKO pada waktu itu adalah merawat orang Islam yang sakit sesuai dengan ajaran Al Our'an dan Sunnah Nabiyullah. Hal yang dikerjakan PKO pada waktu itu ialah menyalurkan jariyah untuk menolong orang sakit.

Kehadiran majelis ini didasari dari spirit Al-Ma'un. Surat Al-Ma'un merupakan spirit dakwah dan tajdid Muhammadiyah. Dalam surat al ma'un dijelaskan tentang hablum 
minallah dan hablum minannas. Kedua hal ini saling berkaitan, jika seorang memiliki hubungan yang buruk kepada sesama manusia dimana dia enggan membantu fakir miskin dan anak yatim maka hubungan dia kepada Allah juga buruk. Karenanya memiliki empati terhadap sesama manusia terutama kaum fakir miskin menunjukkan adanya rasa iman kepada Allah yang baik. Oleh karena itu Muhammadiyah dalam dakwahnya mengembangkan hal tersebut, membantu sesama manusia (Madani, 2017, Gunawan, 2018).

Kehadiran Muhammadiyah di bidang amal usaha kesehatan diharapkan bisa mengangkat harkat dan martabat masyarakat, termasuk kesejahteraan fisik dan rohaninya, sehingga tumbuh kembang menjadi khayra ummah atau umat terbaik.

MPKU dalam melaksanakan tugas dan fungsinya berdasarkan prinsip dan ketentuan yang berlaku dalam Persyarikatan Muhammadiyah. MPKU bckerja melalui berbagai instrumen, sehingga mampu menjalankan usaha dan mencapai tujuan yang digariskan oleh Persyarikatan. Pembinaan-pembinaan yang dilakukan MPKU diarahkan untuk mendukung gerakan dakwah Muhammadiyah.

Amal Usaha Muhammadiyah di bidang kesehatan berada di bawah MPKU. Untuk saat ini amal usaha Muhammadiyah berjumlah 97 Rumah Sakit dan 214 Klinik, dengan rincian sebagai berikut : di Sumatera (6 Rumah Sakit dan 37 Klinik), di Jawa (81 Rumah Sakit dan 141 Klinik), Kalimantan ( 4 Rumah Sakit dan 19 Klinik), Sulawesi (4 Rumah Sakit dan 15 Klinik), Maluku (1 Rumah Sakit), Nusa Tenggara Barat (1 Rumah Sakit dan 1 Klinik) dan Papua (1 Klinik).

Muhammadiyah merupakan gerakan dakwah dan menjadikan amal usahanya sebagai sarana dan media dakwah. Tujuan, visi dan misi amal usaha Muhammadiyah mengikuti arah gerakan Muhammadiyah. Pada Muktamar ke 46 tahun 2010 dirumuskan visi dan misi Muhammadiyah. Secara eksplisit disebut bahwa visi ideal Muhammadiyah adalah : terwujudnya masyarakat islam yang sebenar-benarnya. Sedangkan misi ideal Muhammadiyah terdiri dari 3 aspek, yaitu : Pertama, menegakkan tauhid yang murni berdasarkan al qur'an dan as sunnah. Kedua, menyebarluaskan dan memajukan ajaran islam yang bersumber pada al qur'an dan as sunnah yang shahihah / maqbulah. Ketiga, mewujudkan islam dalam kehidupan pribadi, keluarga dan masyarakat. 
Untuk mewujudkan misi ideal tersebut, Muhammadiyah membuat aturan-aturan berorganisasi dan aturan-aturan dalam amal usahanya berlandaskan ajaran islam yang berdasarkan al qur'an dan as sunnah. Demikian juga kebijakan-kebijakan gerak dakwah muhammadiyah, sehingga bisa terwujud prilaku-prilaku islam dalam kehidupan individu, keluarga, dan masyarakat. MPKU dalam mengarahkan amal usaha kesehatan Muhammadiyah terlah menerbitkan buku Panduan Dakwah Amal Usaha Kesehatan Muhammadiyah yang terdiri dari 2 buku yaitu Buku Utama dan Buku pendamping. Buku ini menjadi acuan bagi Rumah Sakit dan Klinik Muhammadiyah dalam menjalankan amal usaha Muhammadiyah tersebut.

Model pembinaan yang dilakukan MPKU terhadap amal usaha kesehatan bisa dipahami lewat buku pedoman ini. Buku pedoman yang Utama terdiri dari 3 bab. Bab pertama beisikan tentang gerakan Muhammadiyah sebagai gerakan dakwah islam amar makruf nahi mungkar dan berisi amal usaha muhammadiyah sebagai alat dakwah Muhammadiyah. Bab kedua berisi tentang konsep dakwah di Amal Usaha Kesehatan (AUK) Muhammadiyah. Konsep dakwah meliputi dakwah kepada pegawai AUK, dakwah kepada pengunjung dan pasien, dakwah kepada mitra, dakwah kepada pemerintah, dakwah kepada masyarakat. Bab ketiga berisi tentang strategi dakwah di AUK.

Buku pedoman yang Pendamping bersifat aplikatif. Buku ini terdiri dari 9 bab, terdiri dari : bab pertama implementasi pedoman hidup islami warga muhammadiyah, berisikan tentang pedoman memahami buku PHIWM (Pedoman Hidup Islami Warga Muhammadiyah). Bab kedua tentang Tuntunan orang sakit, berisikan hal-hal yang berkaitan dengan orang yang sedang sakit secara psikologi dan anjuran yang harus dilakukan orang sakit menurut islam. Bab ketiga tentang tuntunan kehamilan dan perawatan anak, bab ini menerangkan proses perkembangan janin dalam kandungan dan tuntunan menurut islam bagi wanita hamil hingga melahirkan, kemudian tutunan bagi wanita pasca melahirkan dan menyusui bayi. Bab keempat tentang perilaku islami perawat, dokter dan karyawan di amal usaha kesehatan Muhammadiyah. Bab lima tentang managemen layanan di rumah sakit atau klinik muhammadiyah. Bab enam tentang layanan psikospiritual bagi pengunjung atau pasien dan bagi karyawan di amal usaha 
kesehatan Muhammadiyah. Bab tujuh tentang strandar penanganan bencana. Bab delapan tentang perawatan jenazah secara islam. Bab sembilam penutup.

Dua buku ini menjadi dasar dan pegangan bagi karyawan dan pimpinan amal usaha kesehatan Muhammadiyah untuk menjalankan amal usaha. Aturan yang dipaparkan dalam kedua buku ini sangat lengkap meliputi aspek materi dan spiritual. Buku pedoman yang utama berisikan hal-hal yang bersifat teologis dan ruh dari gerakan Muhammadiyah. Dengan memahami buku ini pelaku amal usaha diharapkan dapat menjadi bagian dari gerakan dakwah Muhammadiyah. Manajeman amal usaha mengikuti semagat dakwah Muhammadiyah. Semangat al maun menjadi ruh manajeman amal usaha, semangat untuk bekerja keras, mau berkorban demi kemanusiaan menjadi ruh manajeman amal usaha kesehatan Muhammadiyah. Dan buku pedoman pendamping berisikan tentang hal-hal yang aplikatif.

Pembinaan yang dilakukan oleh MPKU tersebut merupakan budaya organisasi yang diterapkan kepada amal usaha kesehatan Muhammadiyah. Hal ini diharapkan memberikan hasil yang positif bagi semua pihak. Karyawan mendapatkan perhatian peningkatan SDM yang tidak saja berkaitan dengan pekerjaan tapi berkaitan dengan spriritualitas juga. Model pembinaan yang dikembangkan MPKU ini menjadikan amal usaha kesehatan Muhammadiyah memiliki budaya organisasi yang baik dan berpengaruh pada kepuasan kerja karyawan. Ada pengaruh positif antara budaya organisasi dan kepuasan kerja. Jika di dalam organisasi terdapat misi, konsistensi, adaptabilitas dan pelibatan karyawan terhadap organisasi dalam hal ini di Muhammadiyah, ditemukan berdampak pada kepuasan kerja karyawan (Ali \& Agustian, 2018). Semagat bekerja karyawan menjadi kondusif yang berdampak pada kinerja karyawan dalam berkarya dan bekerja.

Pembinaan yang dilakukan oleh amal usaha kesehatan Muhammadiyah terhadap karyawannya juga berdampak pada sikap pelayanan islami kepada pengunjung rumah sakit atau pasien. Dalam sebuah penelitian yang dilakukan di Rumah Sakit Muhammadiyah Siti Khodijah Gurah Kediri menyimpulkan bahwa ada hubungan positif dan signifikan antara intensitas mengikuti pengajian rutinan Jumat dengan sikap 
pelayanan Islami karyawan rumah sakit Muhammadiyah Siti Khodijah Gurah Kediri (Nisak, 2017).

Peran Muhammadiyah menanggulangi covid 19

Pimpinan Pusat Muhammadiyah pada tanggal 14 Maret 2020 menerbitkan maklumat dengan Nomor: 02/MLM/I.0/H/2020 tentang Wabah Corona Virus Disease (Covid-19). Surat ini tentang pembatasan kegiatan-kegiatan besar atau kegiatan yang melibatkan masa untuk dibatalkan atau ditunda. Sedangkan kegiatan jamaah masjid masih dbolehkan dengan ketentuan agar yang sakit tidak berjamaah. Jika dalam kondisi darurat sholat jumat diganti dengan sholat dhuhur. Kemudian amal usaha kesehatan agar mempersiapkan penanganan Covid-19 diselaraskan dengan protokol kementrian kesehatan dalam koordinasi Majelis Pembina Kesehatan Umum yang bersinergi dengan majelis, lembaga, organisasi otonom,dan amal usaha lain.

Pimpinan Pusat Muhammadiyah juga membentuk Muhammadiyah Covid-19 Command Center (MCCC) yang bertugas mengoordinasikan pelaksanaan program dan aksi penanganan Covid-19. Muhammadiyah Covid-19 Command Center (MCCC) memiliki tim yang terdiri dari perwakilan : (1) Majelis Pembina Kesehatan Umum (MPKU) (2) Muhammadiyah Disaster Management Center (MDMC) (3) 'Aisyiyah

\section{LAZISMU}

2. Majelis Pendidikan Tinggi dan Penelitian Pengembangan (DIKTI LITBANG)

3. Majelis Pendidikan Dasar dan Menengah (DIKDASMEN)

4. Majelis Tabligh

5. Ikatan Pelajar Muhammadiyah (IPM)

6. Ikatan Mahasiswa Muhammadiyah (IMM)

7. Nasyiatul 'Aisyiyah (NA)

8. Hizbul Wathan (HW)

9. Tapak Suci Putera Muhammadiyah (TSPM)

10. Pemuda Muhammadiyah

MCCC melaksanakan tugasnya dalam 3 hal, yaitu [1] mitigasi dan kesiapsiagaan, [2] tanggap darurat, dan [3] recovery pasca bencana. Karena pandemi Covid-19 belum 
usai, MCCC untuk sementara ini memfokuskan kegiatannya dalam 2 hal, yaitu: Pertama, mitigasi dan kesiapsiagaan. Mitigasi dan kesiapsiagaan adalah tindakan antisipatif dan preventif agar Covid-19 tidak semakin menyebar. MCCC aktif melakukan edukasi kepada masyarakat. Edukasi dianggap hal yang paling penting sebagai langkah awal pencegahan Covid-19 dilakukan baik secara langsung maupun melalui online. Edukasi langsung dilakukan dengan turun langung ke masyarakat untuk memberikan informasi yang cukup tentang Covid-19. Sedangkan edukasi online dilakukan dengan menyiapkan situs covid19.muhammadiyah.id yang dapat diakses oleh seluruh lapisan masyarakat untuk mendapatkan informasi dan layanan konseling tentang Covid-19. Kedua, tanggap darurat, yaitu serangkaian kegiatan yang dilakukan dengan segera saat pandemi Covid-19 terjadi (Falahuddin, 2020). Dalam laporan rutin tertanggal 5 Januari 2021, disebutkan bahwa MCCC telah menunjuk sebanyak 84 Rumah Sakit Muhammadiyah dan Aisyiah di seluruh Indonesia sebagai tempat rujukan pasien Covid-19.

Muhammadiyah juga bekerjasama dengan Badan Pembangunan Internasional Amerika Serikat (USAID) dan Kementerian Kesehatan RI dalam meluncurkan sistem informasi yang berfungsi sebagai wadah pembelajaran digital untuk meningkatkan penanganan kasus COVID-19 di jaringan Rumah Sakit Muhammadiyah-Aisyiyah (RSMA). BaSistem, yang berbasis web dan tersedia dalam bentuk aplikasi ini, sekarang membantu 30 fasilitas rujukan COVID-19 Muhammadiyah di dalam jaringan RSMA untuk menerapkan standar protokol perawatan COVID-19 serta meningkatkan pemantauan dan pelaporan pelayanan dan juga perawatan pasien. Sistem ini juga memudahkan konsultasi di antara dokter, yang dapat meningkatkan pengujian dan pengobatan. Hingga saat ini, lebih dari 400 tenaga kesehatan telah dilatih untuk menggunakan sistem ini. Ketua Majelis Pembina Kesehatan Umum (MPKU) Muhammadiyah Agus Samsudin mengatakan kemitraan Muhammadiyah dengan USAID memberikan kontribusi signifikan bagi upaya Indonesia dalam melawan COVID-19. ${ }^{11}$

Respon Majelis Pembina Kesehatan Umum (MPKU) Muhammadiyah dalam menghadapi wabah covid 19 cepat sejalan dengan keputusan dan instruksi Pimpinan Pusat

${ }^{11}$ Perangi COVID-19 di Indonesia, Amerika Gandeng Muhammadiyah (msn.com) diakses tanggal 7 april 2021

Al-Hikkmah: Jurnal Studi Agama-Agama/Vol. 7 , No. 2, 2021 
Muhammadiyah. Di bulan maret 2020 MPKU mempersiapkan 20 rumah sakit Muhammadiyah untuk menerima dan merawat pasien covid 19. Di bulan april terjadi peningkatan menjadi 67 rumah sakit seiring dengan banyaknya pasien covid 19. Di bulan oktober 2020 MPKU menyiapkan 82 rumah sakit Muhammadiyah yang menerima pasien covid 19. Di bulan Januari 2021 MPKU menambah lagi rumah sakit menjadi 84 rumah sakit Muhammadiyah. Di bulan Juni 2021 rumah sakit Muhammadiyah yang dipersiapkan untuk covid 19 menjadi 86 rumah sakit Muhammadiyah.

Strategi Rumah Sakit Muhammadiyah

Majelis Pembina Kesehatan Umum Muhammadiyah mempersiapkan 20 rumah sakit untuk menerima pasien covid 19 setelah keluar keputusan PP Muhammadiyah terkait covid 19, PP Muhammadiyah menginstruksikan kepada amal usaha kesehatan untuk mempersiapkan penerimaan pasien covid 19. Salah satu rumah sakit Muhammadiyah yang ditunjuk untuk menerima pasien covid 19 adalah rumah sakit Siti Khodijah di sepanjang sidoarjo.

Setelah menerima amanah tersebut, maka Rumah Sakit Siti Khodijah Sepanjang menyusun strategi langkah-langkah ${ }^{12}$ sebagai berikut :

- Menyiapkan beb (tempat tidur) untuk pasien covid 19 dengan target $50 \%$ dari ketersediaan

- Melakukan penyuluhan kepada masyarakat terkait covid 19 dan rasa aman untuk ke rumah sakit

- Mengembangkan unit-unit cek covid 19

- Mengembangkan Telemedicine, yaitu pemesanan obat lewat telpon.

- Penundaan Investasi

- Efisiensi biaya operasional

Kemudian langkah-langkah untuk menerima pasien covid 19, RS Siti Khodijah melakukan hal-hal tersebut :

- Menyiapkan kebijakan dan SPO sesuai protokol covid 19,

- Menyiapkan SDM meliputi :

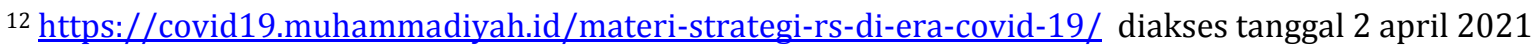


○ Koordinasi keseluruh unit

- Melakukan simulasi covid 19

○ Melakukan job training pengambilan sample civid 19

○ Menambah tim PPI

- Menyiapkan SARPRAS : tempat tidur covid 19

- Menyiapkan APD

- Melakukan penyuluhan ke masyarakat, dalam hal ini dilakukan oleh PKRS (Promosi Kesehatan Rumah Sakit). Penyuluhannya berupa sosialisasi penyakit covid 19 dan membangun kepercayaan masyarakat terhadap rumah sakit yang aman

- Membentuk unit-unit cek covid 19 di kantor dan lembaga (MDU covid 19)

- Menyiapkan OK darurat covid 19 (Ruang Operasi khusus pasien covid 19)

- Melakukan TELEMEDICINE

Alur penanganan pasien di Rumah Sakit Siti Khodijah juga mengalami perubahan. Skrining covid 19 dilakukan sejak awal pasien berkunjung ke rumah sakit. Awal pasien berkunjung ke rumah sakit dilakukan diagnosa dan tes covid 19. Jika hasilnya negatif maka pasien dipersilahkan memasuki jalur hijau dan dipersilahkan berobat sesuai tujuannya, sedangkan jika hasilnya positif covid 19 maka pasien akan ditangani dengan prosedur penanganan pasien covid 19 dan berobat dengan penanganan covid 19.

Dari sisi penyiapan SDM, perawat di Rumah sakit Siti Khodijah sudah melaksanakan job training pengambilan swab, bahkan Rumah sakit Siti Khodijah memberikan penyuluhan dan traning kepada beberapa Rumah Sakit lainnya. Selama pandemi, seluruh karyawan RS Siti Khodijah baik perawat atau non-perawat melakukan pemeriksaan kesehatan terutama covid 19 secara berkala. Di samping itu mereka juga mendapatkan tunjangan sembako seperti beras, gula, telur, susu, dan vitamin C. Insentif petugas yang menangani covid 19 juga diberikan.

Rumah Sakit Siti Khodijah meniadakan jam kunjung pasien. Hal ini dilakukan untuk pencegahan dan penanggulangan infeksi. Kemudian dilakukan juga penyemprotan desinfektan surface ke seluruh ruangan dan area di RS Siti Khodijah tiap tiga jam dan desinfektan udara secara periodik. 
Terhadap pasien Covid-19 dilakukan kohorting dan grouping antara pasien konfirmasi, PDP, maupun ODP, juga melarang adanya pengunjung. Penderita Covid-19 tidak boleh ada penunggunya kecuali pasien anak dan geriatri.

Sosialisasi dan penyuluhan kepada masyarakat juga dilakukan oleh Rumah Sakit Siti Khodijah, dalam hal ini dilakukan oleh PKRS (Promosi Kesehatan Rumah Sakit). Materi PKRS tentang bahaya virus corona, penularan, dan langkah-langkah pencegahan. Lalu, tentang RS Siti Khodijah sebagai RS rujukan dengan perawatan pasien Covid-19 dan non Covid-19 yang terpisah sesuai zona merah dan zona hijau. ${ }^{13}$ Hal ini dilakukan agar masyarakat memahami penyakit covid 19 dan merasa nyaman dan aman untuk berobat ke Rumah Sakit.

Strategi kedepan menghadapi new normal, Rumah Sakit Siti Khodijah menyiapkan strategi sebagai berikut :

- Saat terjadi penurunan pasien covid 19, maka rumah sakit melakukan pengurangan bed covid 19

- Melakukan telemedicine

- Pembuatan OK covid 19 darurat

- Pengembangan MCU

- Pengembangan HD untuk pasien covid 19 ; Instalasi cuci darah khusus untuk pasien covid 19

- Layanan homecare

Penanganan covid 19 di tingkat rumah sakit muhammadiyah dilaksanakan berdasarkan instruksi dari PP Muhammadiyah yang menginstruksikan agar rumah sakit muhammadiyah menerima pasien covid 19. Respon rumah sakit muhammadiyah dalam menanggulangi pandemi covid 19 sangat cepat. Sebagaimana di RS Siti Khodijah, menerima pasien covid 19 diakhir maret 2020 sebanyak 10 pasien covid 19.

Kesimpulan

${ }^{13}$ https://www.republika.co.id/berita/qbakit399/rs-siti-khodijah-sediakan-103-tempat-tidur-pasien-

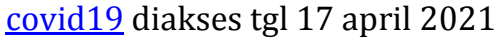


Kesigapan rumah sakit dalam melaksanakan kebijakan PP Muhammadiyah sangat baik dan cepat. Ketika PP Muhammadiyah menginstruksikan untuk menerima pasien covid 19 di awal bulan maret. Rumah sakit muhammadiyah merespon hal tersebut dan menjadi rumah sakit rujukan covid 19. Berbeda dengan rumah sakit swasta pada umumnya yang menunggu dulu untuk menjadi rumah sakit rujukan covid 19.

Strategi MPKU Muhammadiyah dalam menanggulangi pendemi covid 19 dengan menyiapkan rumah sakit Muhammadiyah untuk siap menerima pasien covid 19. Secara bertahap MPKU mempersiapkan rumah sakit Muhammadiyah untuk menerima pasien covid 19. Traning dan pelatihan dari rumah sakit Muhammadiyah yang sudah menerima pasien covid 19 kepada rumah sakit yang belum sering dilakukan. Sebagaimana rumah sakit Siti Khodijah yang sering melakukan job traning kepada rumah sakit Muhammadiyah lainnya. Diawal wabah covid 19 bulan maret 2020, hanya 20 rumah sakit muhammadiyah yang menerima pasien covid 19. Kemudian jumlah itu terus meningkat hingga saat ini di bulan juli 2021 ada 86 rumah sakit Muhammadiyah yang siap menerima pasien covid 19.

Kesigapan rumah sakit Muhammadiyah dalam menghadapi wabah covid 19 merupakan buah dari pembinaan yang dilakukan Muhammadiyah terhadap amal usaha kesehatannya melalui Majelis Pembinaan Kesehatan Umum Muhammadiyah. Strategi pembinaan yang dilakukan MPKU meliputi pembinaan SDM karyawan dan pimpinan amal usaha. Pembinaan SDM tidak hanya sekedar kemampuan dan keterampilan medik yang dikembangkan, namun peningkatan spiritualitas juga dilakukan.

Proses pembinaan yang dilakukan secara bertahap, dimulai dari menselaraskan dan menyamakan visi hidup karyawan dengan visi amal usaha, yaitu mengikuti visi misi muhammadiyah. Proses kedua menanamkan keyakinan atau ruh amal usaha, yang mengikuti ruh dan keyakinan gerakan Muhammadiyah. Proses ketiga, bersikap sesuai dengan ketentuan amal usaha, yang mengikuti amalan warga Muhammadiyah. 


\section{Daftar Pustaka}

Ali, K., \& Agustian, D. W. (2018). Analisis Pengaruh Budaya Organisasi Dan Gaya Kepemimpinan Terhadap Kepuasan Kerja Untuk Meningkatkan Kinerja karyawan Di Rumah Sakit Muhammadiyah Metro. Ilmiah, 12(2).

Falahuddin, F. (2020). Respons Muhammadiyah Menghadapi Covid-19. MAARIF, 15(1). https://doi.org/10.47651/mrf.v15i1.81

Gunawan, A. (2018). Teologi Surat al-Maun dan Praksis Sosial Dalam Kehidupan Warga Muhammadiyah. SALAM: Jurnal Sosial Dan Budaya Syar-I, 5(2). https://doi.org/10.15408/sjsbs.v5i2.9414

Madani, A. B. (2017). DAKWAH DAN PERUBAHAN SOSIAL: STUDI TERHADAP PERAN MANUSIA SEBAGAI KHALIFAH DI MUKA BUMI. LENTERA: Jurnal Ilmu Dakwah Dan Komunikasi, 1(01). https://doi.org/10.21093/lentera.v1i01.851

Nisak, C. (2017). HUBUNGAN ANTARA INTENSITAS MENGIKUTI PENGAJIAN RUTINAN JUMAT DENGAN SIKAP PELAYANAN ISLAMI KARYAWAN RUMAH SAKIT MUHAMMADIYAH SITI KHODIJAH GURAH KEDIRI. Spiritualita, 1(2). https://doi.org/10.30762/spr.v1i2.645

Tim Majelis Pembina Kesehatan Umum Muhammadiyah (2017), Buku utama PANDUAN DAKWAH AMAL USAHA KESEHATAN MUHAMMADIYAH, Suara Muhammadiyah, Yogyakarta

Tim Majelis Pembina Kesehatan Umum Muhammadiyah (2017), Buku Pendamping PANDUAN DAKWAH AMAL USAHA KESEHATAN MUHAMMADIYAH, Suara Muhammadiyah, Yogyakarta

https://www.liputan6.com/health/read/4323369/menilik-awal-mula-perjalanan-covid-19-pada-31desember-2019 diakses tanggal 2 april 2021

http://indonesiabaik.id/infografis/mengenal-hubungan-covid-19-dan-sars-cov-2 diakses tgl 2 april 2021

https://health.detik.com/berita-detikhealth/d-5240992/perjalanan-8-bulan-pandemi-virus-coronacovid-19-di-indonesia diakses tanggal 2 april 2021 
WHO Coronavirus (COVID-19) Dashboard / WHO Coronavirus Disease (COVID-19) Dashboard diakses tanggal 2 april 2021

https://www.viva.co.id/berita/nasional/1226139-pendapatan-anjlok-banyak-rumah-sakit-terancambangkrut-akibat-pandemi diakses tanggal 4 April 2021

https://kumparan.com/pandangan-jogja/pandemi-covid-19-membuat-keuangan-rumah-sakitterancam-bangkrut-1tgkkVYZo]8/full diakses tanggal 4 april 2021

https://www.antaranews.com/berita/1846888/jokowi-apresiasi-peran-muhammadiyah-padakesehatan-dan-ekonomi diakses 18 april 2021

Muhammadiyah Membangun Kesehatan Bangsa | Suara Muhammadiyah diakses tanggal 2 april 2021 https://www.umy.ac.id/pku-muhammadiyah-ide-briliant-kh-sudja-yang-ditertawakan.html diakses 17 april 2021

https://rspkujogja.com/2014/09/07/sejarah/\#: :text=RS\%20PKU\%20Muhammadiyah\%20Yogyakart a\%20milik,kampung\%20Jagang\%20Notoprajan\%20No.72 diakses tanggal 16 april 2021

Perangi COVID-19 di Indonesia, Amerika Gandeng Muhammadiyah (msn.com) diakses tanggal 7 april 2021

https://covid19.muhammadiyah.id/materi-strategi-rs-di-era-covid-19/ diakses tanggal 2 april 2021 https://www.republika.co.id/berita/qbakit399/rs-siti-khodijah-sediakan-103-tempat-tidur-pasiencovid19 diakses tgl 17 april 2021 